\title{
Correction to: Apples and Peaches-Consumer Protection Goes East
}

\author{
T. Meyer ${ }^{1}$ \\ Published online: 19 February 2020 \\ (C) Springer Science+Business Media, LLC, part of Springer Nature 2020
}

\section{Correction to: Journal of Consumer Policy https://doi.org/10.1007/s10603-019-09432-1}

The original version of this article unfortunately contains incorrect author name.

The corrected author name is presented in this correction article.

The original article has been corrected.

The online version of the original article can be found at https://oi.org/10.1007/s10603-019-09432-1

T. Meyer

thomas.meyer@giz.de

1 Deutsche Gesellschaft für Internationale Zusammenarbeit (GIZ) GmbH, 42, Rustaveli Ave/31a, Griboedov St, 0108 Tbilisi, Georgia 